Témoigner Témoigner. Entre histoire et mémoire

Getuigen Revue pluridisciplinaire de la Fondation Auschwitz

$125 \mid 2017$

Histoire et mémoire de la persécution des

homosexuel-le's par les nazis

\title{
Staats-herinnering en staat van de herinnering
}

Mémoire d'État et état de la mémoire

\section{Frédéric Crahay}

Traducteur : Anneleen Spiessens

\section{(2) OpenEdition}

Journals

Édition électronique

URL : https://journals.openedition.org/temoigner/6009

DOI : 10.4000/temoigner.6009

ISSN : 2506-6390

Cet article est une traduction de :

Mémoire d'État et état de la mémoire - URL : https://journals.openedition.org/temoigner/6005 [fr]

Éditeur :

Éditions du Centre d'études et de documentation Mémoire d'Auschwitz, Éditions Kimé

Édition imprimée

Date de publication : 1 octobre 2017

Pagination : 4

ISBN : 978-2-930953-01-4

ISSN : 2031-4183

Référence électronique

Frédéric Crahay, «Staats-herinnering en staat van de herinnering», Témoigner. Entre histoire et mémoire [Online], 125 | 2017, Online op 24 décembre 2021, geraadpleegd op 03 février 2022. URL: http:// journals.openedition.org/temoigner/6009; DOI: https://doi.org/10.4000/temoigner.6009 
$\rightarrow$ Frédéric Crahay, hoofd van de redactie Vertaling uit het Frans: Anneleen Spiessens

\section{Staats-} herinnering

en staat van de herinnering

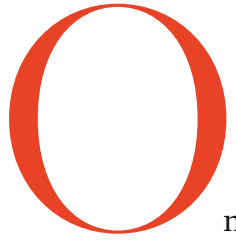

ns redactioneel stuk van april 2017 ging over het Tweede Wereldoorlogmuseum in Gdańsk en de aanvaring van de directie met de Poolse regering. Sinds de inhuldiging in januari en de opening in maart van dit jaar wordt het museum geviseerd door de Poolse minister van Cultuur, Piotr Gliński van de partij Recht en Rechtvaardigheid. Hij weigerde aanwezig te zijn tijdens de inhuldiging en dreef op die manier een gespannen situatie verder op de spits. De scenografie van de tentoonstelling zou de heldendaden en zelfopoffering van de Poolse staat onvoldoende belichten en zou in het algemeen te 'Europees' zijn. De tentoonstelling is op dit moment nog steeds te bezichtigen, maar professor Paweł Machcewicz is wel directeur af. Machcewicz, historicus aan de Universiteit van Warschau, kwam in mei 2017 naar België en vertelde hoe zeer hij onder druk was gezet. In een interview met Le Soir op 3 juni verklaarde hij dat de strijd begon in 2008, bij de start van het museumproject. Het Poolse parlement had toen kritiek geuit op het brede panel van historici dat was geraadpleegd, enkel en alleen omdat niet alle leden over de Poolse nationaliteit beschikte. Een andere, al even onrustwekkende opmerking voor een parlement dat de democratie zou moeten vertegenwoordigen had betrekking op het feit dat het museum de aandacht te veel zou vestigen op het lot van de burgers. En dat terwijl de grote meerderheid van de slachtoffers tijdens de Tweede Wereldoorlog juist burgers waren, en dat het dus ook in die zin een heel ongewone oorlog was... Dat doet het ergste vermoeden voor de nieuwe koers die kersvers directeur Karol Nawrocki, benoemd op 6 april, zal varen. Hij gaf al aan de tentoonstelling niet alleen inhoudelijk te willen wijzingen, maar ook het materiaal op een andere manier te gaan presenteren. Nochtans tekende het Poolse publiek massaal present in de eerste maanden na de opening en lieten bezoekers bemoedigende reacties optekenen voor de bedenkers van het oorspronkelijke project. Ook Poolse historici lieten van zich horen. Een steunbetuiging aan het huidige museum werd door een honderdtal van hen ondertekend. Maar zal dat voldoende zijn om een grove herschrijving van de geschiedenis te voorkomen?

In België herdenken we ondertussen dat 75 jaar geleden de deportatie aanving van Joodse burgers vanuit de Dossinkazerne in Mechelen naar het uitroeiingscentrum van Auschwitz-Birkenau. Ook de razzia's van de zomer 1942 in Antwerpen en Brussel verdienen hierbij aandacht. Ter herinnering: tussen 1942 en 1944 werden 25528 mensen gedeporteerd met 28 transporten (waarvan eentje met 354 Roma en Sinti). 1251 keerden terug. De treinkonvooien gingen symbool staan voor de deportatie naar de dood. De kelder van de Kazerne Dossin vormt een sleutelplek in deze geschiedenis. Het memoriaal dat zich daar momenteel bevindt, wordt volgend jaar onder handen genomen om het een menselijker en minder 'kil' uitzicht te geven, in tegenstelling dus tot wat men in het museum van Gdańsk probeert te doen. De Kazerne is een plek van geschiedenis en herinnering, en beschikt sinds kort over haar eigen naslagwerk: in juni publiceerde Laurence Schram Dossin, L'antichambre d'Auschwitz bij uitgeverij Racine. Talrijke getuigenissen van overlevenden vormen de rode draad doorheen haar verhaal en zullen de herdenking van de deportatie uit België alvast een menselijker gelaat geven. 